\title{
ERRATUM
}

\section{Erratum to: Quality of Life in Glaucoma: A Review of the Literature}

\author{
Luciano Quaranta · Ivano Riva · Chiara Gerardi · Francesco Oddone • \\ Irene Floriani · Anastasios G. P. Konstas
}

Published online: May 11, 2016

(C) The Author(s) 2016. This article is published with open access at Springerlink.com

Erratum to: Adv Ther

DOI 10.1007/s12325-016-0333-6

In the original publication, the fifth author's name was incorrectly published as Irene Floriano on the title page and within the disclosures section. The correct name should read as "Irene Floriani".

The online version of the original article can be found under doi:10.1007/s12325-016-0333-6.

L. Quaranta $(\varangle) \cdot$ I. Riva

Department of Medical and Surgical Specialties,

Radiological Sciences and Public Health, University

of Brescia, Brescia, Italy

e-mail: luciano.quaranta@unibs.it

C. Gerardi · I. Floriani

IRCCS-Istituto di Ricerche Farmacologiche Mario

Negri, Milan, Italy

F. Oddone

IRCCS-Fondazione G.B. Bietti, Rome, Italy

A. G. P. Konstas

1st and 3rd University Departments of

Ophthalmology, Aristotle University of

Thessaloniki, Thessaloniki, Greece
Open Access. This article is distributed under the terms of the Creative Commons Attribution-NonCommercial 4.0 International License(http://creativecommons.org/licenses/ by-nc/4.0/), which permits any noncommercial use, distribution, and reproduction in any medium, provided you give appropriate credit to the original author(s) and the source, provide a link to the Creative Commons license, and indicate if changes were made. 